\title{
Model of wetland development of the Amapá coast during the late Holocene
}

\author{
JOSÉ T.F. GUIMARÃES ${ }^{1}$, MARCELO C.L. COHEN ${ }^{1,2}$, MARLON C. FRANÇA ${ }^{1}$, \\ RÚBEN J. LARA ${ }^{3}$ and HERMANN BEHLING ${ }^{4}$ \\ ${ }^{1}$ Programa de Pós-Graduação em Geologia e Geoquímica, Laboratório de Dinâmica Costeira \\ Universidade Federal do Pará, Av. Perimetral 2651, Terra Firme, 66077-530 Belém, PA, Brasil \\ ${ }^{2}$ Faculdade de Oceanografia, Universidade Federal do Pará, Rua Augusto Corrêa, 1, Guamá, 66075-110 Belém, PA, Brasil \\ ${ }^{3}$ Center for Tropical Marine Ecology (ZMT), Fahrenheitstr. 6, 28359 Bremen, Germany \\ ${ }^{4}$ Department of Palynology and Climate Dynamics, Albrecht-von-Haller-Institute for Plant Sciences \\ University of Göttingen, Untere Karspüle 2, 37073 Göttingen, Germany \\ Manuscript received on September 23, 2008; accepted for publication on May 14, 2009
}

\begin{abstract}
The modern vegetation types, sedimentary sequences, pollen records and radiocarbon dating obtained from three sediment cores from Calçoene Coastal Plain were used to provide a palaeoecological history during the late Holocene of Amapá coastal wetland according to flood regime, sea-level and climatic changes. Based on these records, four phases of vegetation development are presented and they probably reflect the interaction between the flow energy to the sediment accumulation and the brackish/freshwater influence in the vegetation. This work suggests interchanges among time periods characterized by marine and fluvial influence. The longitudinal profile did not reveal the occurrence of mangrove in the sediment deposited around $2100 \mathrm{yr}$ B.P. During the second phase, the mud progressively filled the depressions and tidal channels. The mangrove probably started its development on the channel edge, and the herbaceous field on the elevated sectors. The third phase is characterized by the interruption of mangrove development and the increase of "várzea" vegetation that may be due to the decrease in porewater salinity related to a decrease in marine water influence. The last phase is represented by the mangrove and "várzea" increase. The correlation between current patterns of geobotanical unit distribution and palaeovegetation indicates that mangrove and "várzea" forests are migrating over the herbaceous field on the topographically highest part of the studied coast, which can be related to a relative sea-level rise.
\end{abstract}

Key words: Amazon river, climatic changes, mangrove, palynology, sea-level.

\section{INTRODUCTION}

Mangroves are the most favorable environment for palaeoclimatic studies during the Holocene because of their high sedimentation rates and susceptibility to climatic and sea-level changes (Gornitz 1991). Hence, the sediments deposited beneath mangrove vegetation provide useful indications of tidal regime (Scholl 1964, Woodroffe 1981, Van de Plassche 1986). Furthermore,

Correspondence to: José Tasso Felix Guimarães E-mail: tasso@ufpa.br the relative proportion between mangrove and "várzea" vegetation contributes to the study of fresh and brackishwater influence, as mangroves are more tolerant to soil salinity (Lacerda et al. 1995, Youssef and Saenger 1999, Alongi et al. 2000) than "várzea" forest (GonçalvesAlvim et al. 2001). Soil salinity is basically controlled by flooding frequency and position along the estuarine gradient (Lara and Cohen 2006).

Regarding the Amapá coastal plain, the mangrove community presents a zonation parallel to the shoreline (Boaventura and Narita 1974). These zones are gener- 
ally the response of individual mangrove species to the gradients of flooding frequency (Cohen and Lara 2003), waterlogging (Hutchings and Saenger 1987), nutrient availability (Junk 1997), soil salinity across the intertidal area (Wolanski et al. 1990) and volume of river water discharge, which depends of regional rainfall (Mörner 1999, Cohen et al. 2005b).

Palaeoecological and sedimentologial studies in the Amazon basin during the Late Pleistocene and Holocene have suggested that dryer periods correspond to less precipitation and reduced river discharge (e.g. Colinvaux and De Oliveira 2000, Vital and Stattegger 2000, Maslin et al. 2000). Thus, interchanges between dry and wet periods may have significant impacts on coastal wetland, as they modify the soil salinity gradients and the soil moisture (Cohen et al. 2005a).

In a previous work using remote sensing (Cohen and Lara 2003), pollen analysis, and radiocarbon dating, it was possible to identify the impact of climatic changes during the last thousand years on the eastern sector of the Amazonian mangroves (Behling et al. 2001, 2004, Cohen et al. 2005a, b, 2008, Lara and Cohen 2008). Using these same tools, this work presents a model of wetland development of the Amapá coast during the late Holocene.

\section{STUDY AREA}

The study site is located close to the city of Calçoene on the Amapá coast, in the eastern Amazon region (Fig. 1). Allison et al. (1990) identified coastal mudflat colonized by mangroves and marshes. According to Boaventura and Narita (1974), this region is characterized by Holocene deposits formed in a fluviomarine coastal plain with tidal influence. The area with muddy deposits is mainly colonized by mangroves. The tidal range is about $5.2 \mathrm{~m}$ and the current velocities reach $2 \mathrm{~m} / \mathrm{s}$ (Schaeffer-Novelli and Cintron-Molero 1988).

Modern vegetation of the Calçoene is represented by "terra firme" (Amazon coastal forest) vegetation $\left(10.288 \mathrm{~km}^{2}\right)$, savanna $\left(1.236 \mathrm{~km}^{2}\right)$, mangrove, "várzea" and flooded herbaceous plain $\left(2.808 \mathrm{~km}^{2}\right)$ (Morais and Morais 2000). The periodically inundated herbaceous field occurs on the limit of the tidal influence and it is represented mainly by Poaceae, Cyperaceae, Nymphaceae, Alismataceae, Araceae and Maranthaceae. Fol- lowing the topographical gradient, there is a permanently inundated herbaceous field composed of "aguapé" (Eichornia crassipes (Mart.), "cabomba" (Cabomba aquatica DC.) and "mururé" (Nynphaea sp.) in some sectors with small depressions that have no significant inflows, outflows and peat accumulation (Costa Neto 2004). The "várzea" vegetation includes "tiriricão" (Scleria sp.), "aninga" (Montrichardia arborescens L. Schott), "buriti”" (Mauritia flexuosa L.f.), "açaí" (Euterpe oleracea Mart.), "mururés" (Eichornia sp.) and "piri" (Cyperus giganteus Vahl.). The mangroves present the Avicennia nitida Jacq., Avicennia germinans (L.) Stearn, Rhizophora mangle L., Laguncularia sp. and Laguncularia racemosa Gaertn. (Leite et al. 1974).

The following units represent the vegetation of study site: Amazon coastal forest, "várzea", herbaceous field and mangrove (Fig. 1). Calçoene mangroves present an area of about $311 \mathrm{~km}^{2}$ and are densely covered of forests, mainly by Avicennia, Rhizophora, and Laguncularia, from the high spring tide to the mean tidal level. The hinterland mangrove makes contact with the herbaceous field $\left(1.201 \mathrm{~km}^{2}\right)$ mainly represented by Cyperaceae and Poaceae, conditioning the development of discontinuous fringes. The "várzea" forests are generally represented by Mauritia flexuosa L.f., Eichornia sp., and Euterpe oleracea Mart. They cover an area of about $684 \mathrm{~km}^{2}$, which is influenced by periodic floods of sediment loaded, nutrient-rich fresh water rivers. Only a few sectors of topographically elevated areas are covered by the Amazon coastal forest $\left(18 \mathrm{~km}^{2}\right)$.

\section{MATERIALS AND METHODS}

\section{Remote Sensing Data And Image Processing}

Characterization and spatial distribution of the main geobotanical units were carried out by satellite image interpretation aided by field validation. The Landsat ETM+ (225/058, 225/059, 226/057, 226/058 and 226/ 059) images acquired on September 2000 were purchased from the National Institute of Space Researches - Brazil (INPE). The dataset, processed using the Spring 4.3 software, was geometrically corrected through another ETM+ image previously corrected, and later resampled with a nearest neighbor interpolation to $30 \mathrm{~m}$ pixels. 


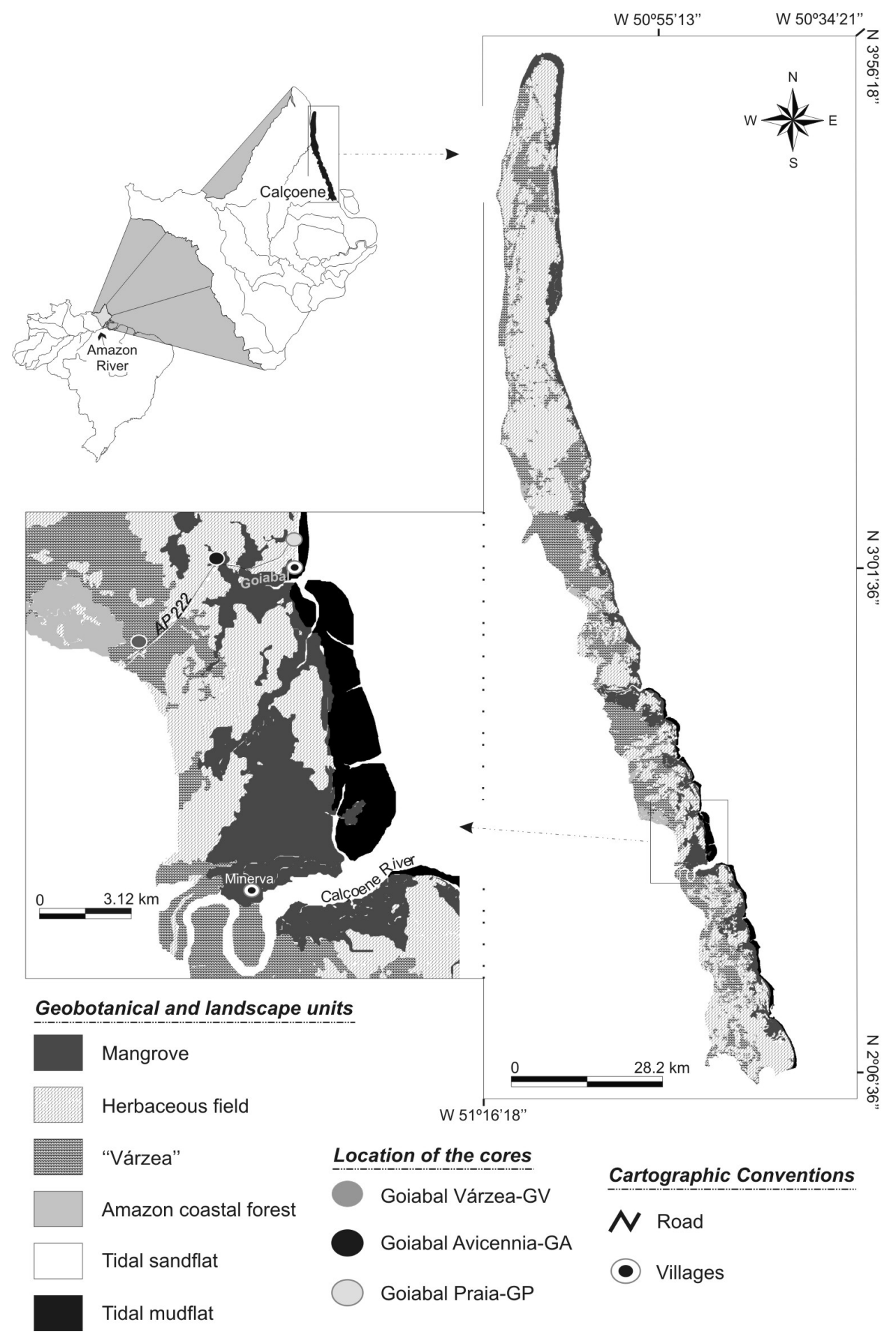

Fig. 1 - Study site.

The radiometric correction was related to the attenuation of atmospheric effects and was based on the minimum histogram pixel approach (Chavez 1988). Image enhancements were applied based on linear and equalization stretches. The three bands for a red-green-blue (RGB) color composite (TM4, TM5 and TM3 bands) 
JOSÉ T.F. GUIMARÃES et al.

were selected based on the optimum index factor scheme (Chavez et al. 1982), and chosen for visual interpretation. Validation was assisted by allocating ground control points for the classification of different phytophysiognomies. The typical species of plants in each unit was documented by photographic documentation and GPS measurements. These sites were located in a Geographic Information System (GIS) by matching and distinguishing botanical formations.

\section{SAmpling And SAmple Processing}

Three sediment cores were collected using a Russian Sampler. The geographical position of the cores was determined by GPS. Sediment color was classified according to the Rock-Color Chart (Goddard et al. 1984).

The cores were sampled from an area colonized by

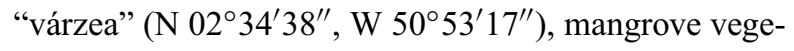
tation ( $\left.02^{\circ} 35^{\prime} 59^{\prime \prime}, \mathrm{W} 50^{\circ} 52^{\prime} 08^{\prime \prime}\right)$ and on a tidal sandflat ( $02^{\circ} 36^{\prime} 48^{\prime \prime}$, W $\left.50^{\circ} 50^{\prime} 41^{\prime \prime}\right)$, and they were called Goiabal Várzea - GV (1.45 meter depth), Goiabal Avicennia - GA (1.65 meter depth) and Goiabal Praia - GP (1.45 meter depth), respectively (Fig. 1).

For pollen analysis, $1 \mathrm{~cm}^{3}$ sediment samples were taken at $5 \mathrm{~cm}$ intervals along the cores. Prior to processing the sediment, one tablet of exotic Lycopodium spores was added to each sample for the calculation of pollen concentration (grains $/ \mathrm{cm}^{3}$ ) and pollen accumulation rates (grains $/ \mathrm{cm}^{2} / \mathrm{yr}$ ). All samples were prepared using standard pollen analytical techniques including acetolysis (Faegri and Iversen 1989). Sample residues were mounted in a glycerin gelatin medium. Identification of pollen grains and spores were based on pollen morphological descriptions (Roubik and Moreno 1991, Herrera and Urrego 1996, Colinvaux et al. 1999). Samples were counted to a minimum of about 300 pollen grains or to 100-200 pollen grains in the case of samples with a low pollen concentration. The total pollen sum excludes fern spores, fungal spores, algae and microforaminifers. Pollen and spore data are presented in pollen diagrams as percentages of the total pollen sum. Taxa were grouped into mangrove, herbaceous field, "várzea" and Amazon coastal forest. The softwares Tilia and Tilia Graph were used to the calculation and plot of the pollen diagrams (Grimm 1987).

\section{RADIOCARBON DATING}

Three bulk samples of $2 \mathrm{~cm}^{3}$ each were used for radiocarbon dating. The sediment samples were checked and mechanically cleaned under the microscope. The residual material was then extracted with $1 \% \mathrm{HCl}, 1 \% \mathrm{NaOH}$ at $60^{\circ} \mathrm{C}$, and again $1 \% \mathrm{HCl}$ (alkali residue). The alkali extraction of the organic fractions (humic acids) was precipitated with $\mathrm{HCl}$, washed and dried. The ${ }^{14} \mathrm{C}$ concentration of the samples was measured by comparing the simultaneously collected ${ }^{14} \mathrm{C},{ }^{13} \mathrm{C}$, and ${ }^{12} \mathrm{C}$ beams of each sample with those of Oxalic Acid standard $\mathrm{CO}_{2}$ and coal background material. The samples were analyzed by the Accelerator Mass Spectrometry (AMS) at the Leibniz Laboratory of Isotopic Research at the Christian-Albrechts University in Kiel (Germany). The calibration of the radiocarbon dates was carried out following Stuiver et al. (1998). The results are reported in calibrated years before 1950 AD. (cal yr B.P.) with precision of $2 \sigma$.

\section{RESULTS}

\section{TeXtural Description of SEDiment Cores}

The sediment cores from the Amapá coast were zoned in sixteen segments based on color gradient and qualitative grain size descriptions (Table I). The $145 \mathrm{~cm}$ long Goiabal Várzea - GV core is mainly composed of homogeneous pelitic sediments rich in organic matter at the top. The core base $(145-90 \mathrm{~cm})$ shows grayish orange silty clay with light gray spots that grade upward into light gray mud $(90-70 \mathrm{~cm})$ and dark gray organic clay compacted $(70-40 \mathrm{~cm})$ in the middle of the core. A brown organic mud bioturbated with abundant root and leaf remains dominates the last segment (40$0 \mathrm{~cm}$ ). The $165 \mathrm{~cm}$-long Goiabal Avicennia - GA core consists of five muddy units, including: a lower (165$125 \mathrm{~cm}$ ) dark brown unit, with decomposed plants and milimetric root marks; three intermediate $(125-105 \mathrm{~cm}$; 105-90 cm; 90-40 cm) light and dark gray units; and an upper $(40-0 \mathrm{~cm})$ dark yellow unit with interbeddings of fine-grained sands. The $145 \mathrm{~cm}$-long Goiabal Praia - GP core presents massive sand and silty sand with colors ranging from brown, grayish brown to yellowish brown and plants with a variable degree of decomposition from base to top. 
TABLE I

Textural description of the sediment cores.

\begin{tabular}{c|c|c}
\hline Core & Depth $(\mathrm{cm})$ & Textural description \\
\hline \multirow{4}{*}{ Goiabal Várzea } & $0-40$ & Brown organic mud bioturbated \\
\cline { 2 - 3 } & $40-70$ & Dark gray organic clay, compact \\
\cline { 2 - 3 } & $70-90$ & $\begin{array}{c}\text { Light gray mud with dark gray and grayish } \\
\text { orange spots }\end{array}$ \\
\cline { 2 - 3 } & $90-145$ & Grayish orange silty clay with dark grey spots, \\
very compact
\end{tabular}

\section{RADIOCARbon DATES AND SEDIMENTATION RATES}

Radiocarbon dating of the GV core at $70 \mathrm{~cm}$ (KIA28169), GA core at $127 \mathrm{~cm}$ (KIA-28170) and GP core at $137 \mathrm{~cm}$ (KIA-28171) depths yielded ages of $2100 \pm$ $60,970 \pm 35$ and $3490 \pm 140$ cal yr B.P, respectively. The calculated sedimentation rates, based on the calibrated radiocarbon dates (Table II), are about $0.33 \mathrm{~mm} /$ yr (GV), $1.3 \mathrm{~mm} / \mathrm{yr}(\mathrm{GA})$ and $0.39 \mathrm{~mm} / \mathrm{yr}$ (GP), which are similar to sedimentation rates from other areas of the Pará coast, for instance, $0.3-1 \mathrm{~mm} / \mathrm{yr}$ in the Marajó Island (Behling et al. 2004, Cohen et al. 2008), and $0.3-1.3 \mathrm{~mm} / \mathrm{yr}$ in Taperebal (western Bragança) and Bragança Peninsula (Cohen et al. 2005a, Vedel et al. 2006). Besides, the sedimentation rates estimated in the study site are within the vertical accretion range of 8 to $0.1 \mathrm{~mm} / \mathrm{yr}$ recorded in other mangrove forest (e.g. Bird 1980, Spenceley 1982, Cahoon and Lynch 1997).

Palaeoenvironmental studies on the Pará coast indicate a decrease in the sedimentation rate from the low to the topographically higher limit of the mangrove areas (Cohen et al. 2005a, Behling et al. 2001), which al- lowed to propose a model of Holocene mangrove development to Bragança Peninsula-northern Brazil (Cohen et al. 2005b). Thus, the similar sedimentation rates between the Pará coast and the study site suggest that these sediments accumulated in a continuous way.

\section{Pollen DATA}

Based on the pollen analyses of the GV, GA and GP cores (Fig. 1), three pollen profiles were developed, which show the different paleovegetation zones (Figs. 2, 3 and 4).

\section{Goiabal VÁRZEa RECord}

The GV core base, in Zone GV-1 (145-65 cm, 16 samples for pollen analysis), does not present pollen concentration suitable for statistical analysis. However, in Zone GV-2 (65-60 cm, 2 samples) a sedimentary unit occurs mainly with herbaceous pollen, constituted by Poaceae (40-45\%) and Cyperaceae (5-20\%). "Várzea" pollen is frequent and consists of Euphorbiaceae (18\%) and Mauritia (2-11\%). After this herbaceous field zone, the pollen becomes progressively less frequent, 
JOSÉ T.F. GUIMARÃES et al.

TABLE II

Radiocarbon dates (AMS) of the samples.

\begin{tabular}{c|c|c|c|c}
\hline Sample & Lab. number & Depht $(\mathrm{cm})$ & $\begin{array}{c}\text { Conventional } \\
\text { C-14 age (yr B.P.). }\end{array}$ & $\begin{array}{c}\text { Calibrated } \\
14 \\
\text { C age (yr B.P.) }\end{array}$ \\
\hline Goiabal Várzea & KIA-28169 & 70 & $2140 \pm 25$ & $2100 \pm 60$ \\
\hline Goiabal Avicennia & KIA-28170 & 127 & $1070 \pm 25$ & $970 \pm 35$ \\
\hline Goiabal Praia & KIA-28171 & 137 & $3260 \pm 70$ & $3490 \pm 140$ \\
\hline
\end{tabular}

which characterizes again a barren interval with coal fragments restricted to Zone GV-3 $(60-40 \mathrm{~cm}, 3 \mathrm{sam}-$ ples). The next zone, GV-4 (40-30 cm, 3 samples), is represented by Poaceae (16-95\%), Cyperaceae (2$16 \%)$, Asteraceae $(0-25 \%)$, Arecaceae $(0-20 \%)$ and Mimosa (0-5\%) pollen, which represent an herbaceous vegetation assembly. The top of GV core (Zone GV$5,30-0 \mathrm{~cm}, 6$ samples) is dominated by Euphorbiaceae (2-70\%), Rubiaceae (2-60\%), Fabaceae (2-25\%), Byrsonima $(0-47 \%)$ and Mauritia (0-14\%) pollen, which characterizes the current "várzea" vegetation (Fig. 2).

\section{Goiabal Avicennia ReCord}

The GA core bottom, in Zone GA-1 (165-100 cm, 14 samples), is marked by the dominance of herbaceous field pollen, mainly constituted by Poaceae (25-97\%) and Cyperaceae (5-36\%). The mangrove pollen percentage, represented by Avicennia (0-53\%) and Rhizophora $(0-25 \%)$, increases to the top of this zone. However, the samples in the Zone GA-2 (100-70 cm, 5 samples) did not present pollen (barren interval).

The next zone, GA-3 (70-40 cm, 6 samples), reveals a heterogeneous vegetation assembly. This zone is characterized by the herbaceous, Amazon coastal forest and mangrove pollen grains, mainly represented by Cyperaceae (6-40\%) Poaceae (5-30\%), Asteraceae (2-5\%), Rubiaceae (5-20\%), Fabaceae (0-30\%), Euphorbiaceae (0-10\%), Anarcadiaceae (0-10\%), Rhizophora (0-33\%) and Avicennia (0-15\%).

In the Zone GA-4 (40-10 cm, 7 samples), the herbaceous field (48-70\%) and the Amazon coastal forest pollen (15-35\%) are well represented, while the mangrove pollen decreases significantly $(2-15 \%)$. However, the Amazon coastal forest and herbaceous pollens decrease progressively until Zone GA-5 $(10-0 \mathrm{~cm}, 2 \mathrm{sam}-$ ples), which is marked by the mangrove pollen, mainly represented by Avicennia (35-40\%) and Rhizophora
(5-10\%). Nowadays, the study site is mainly colonized by Avicennia trees.

\section{Goiabal Praia Record}

The Goiabal praia-GP core presents, for each sample, a mean pollen amount of one hundred (Fig. 4). The Zone GP-1 (145-80 cm, 13 samples) reveals a sector that was either unproductive or that contains only a few pollen grains. The next zone, GP-2 (80-30 cm, 11 samples), is characterized by the herbaceous, Amazon coastal forest and mangrove pollens, mainly represented by Poaceae (2-65\%), Cyperaceae (1-5\%) and Avicennia (2-10\%). This vegetation assembly probably indicates a sediment deposition in a transition environment between herbaceous field and mangrove. In Zone GP-3 (30-0 cm, 6 samples) the pollen becomes less frequent, which characterizes again a barren interval.

In the case of the GP core, the low pollen quantity is probably due to the sediment grain size, because this core is constituted basically of sand. Grain size is the main factor determining the pollen preservation (Colinvaux et al. 1999). The pollen fixed in muddy sediments generally presents better preservation (Cohen 2003) ahead of the effects of biochemical action on pollen and spore structure (Sangster and Dale 1961, 1964).

\section{DISCUSSION}

\section{The Pollen Signal in the Sediment}

From the viewpoint of the palynology, there often exists two pollen components in sediment-pollen from "local" vegetation (the crown of the hat), and background pollen from "regional" vegetation (the brim of the hat) (Andersen 1970, Janssen 1973, Sugita 1994). The terms are useful, even though the distinction cannot be drawn sharply: the transition between the crown and brim is gradual, and the sizes of the crown and brim will differ for each pollen taxon (Davis 2000). 


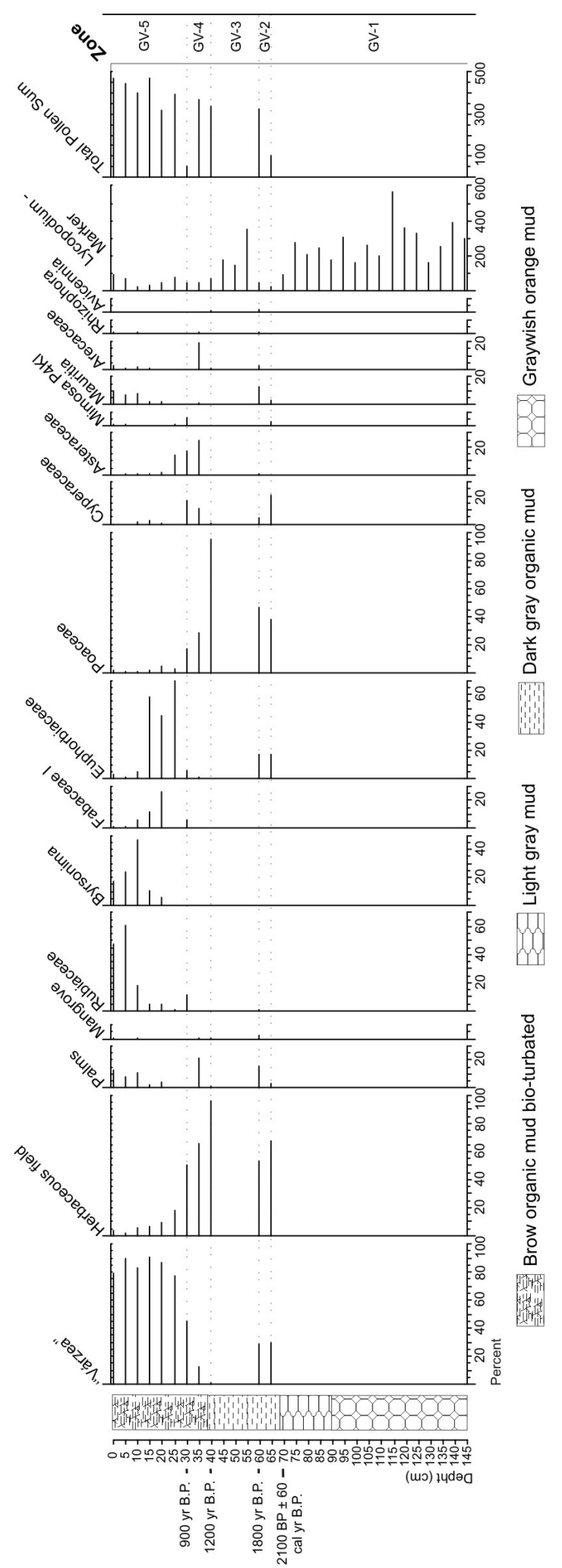

Fig. 2 - Textural description integrated to the pollen profile along the Goiabal Várzea core. 


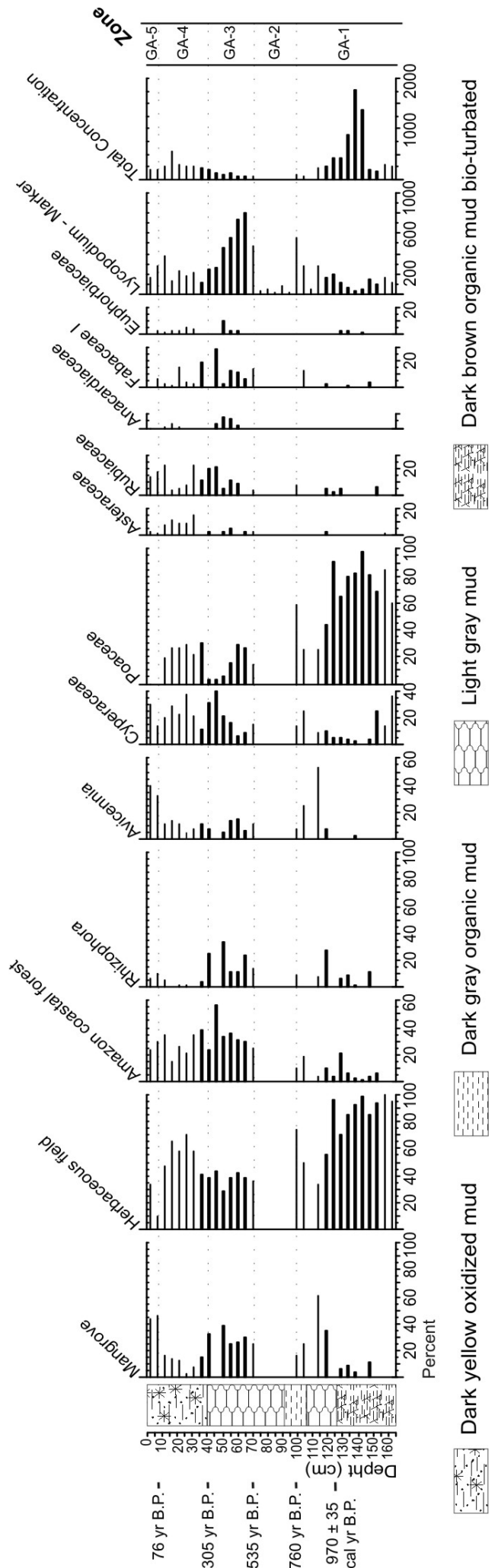

Fig. 3 - Textural description integrated to the pollen profile along the Goiabal Avicennia core. 


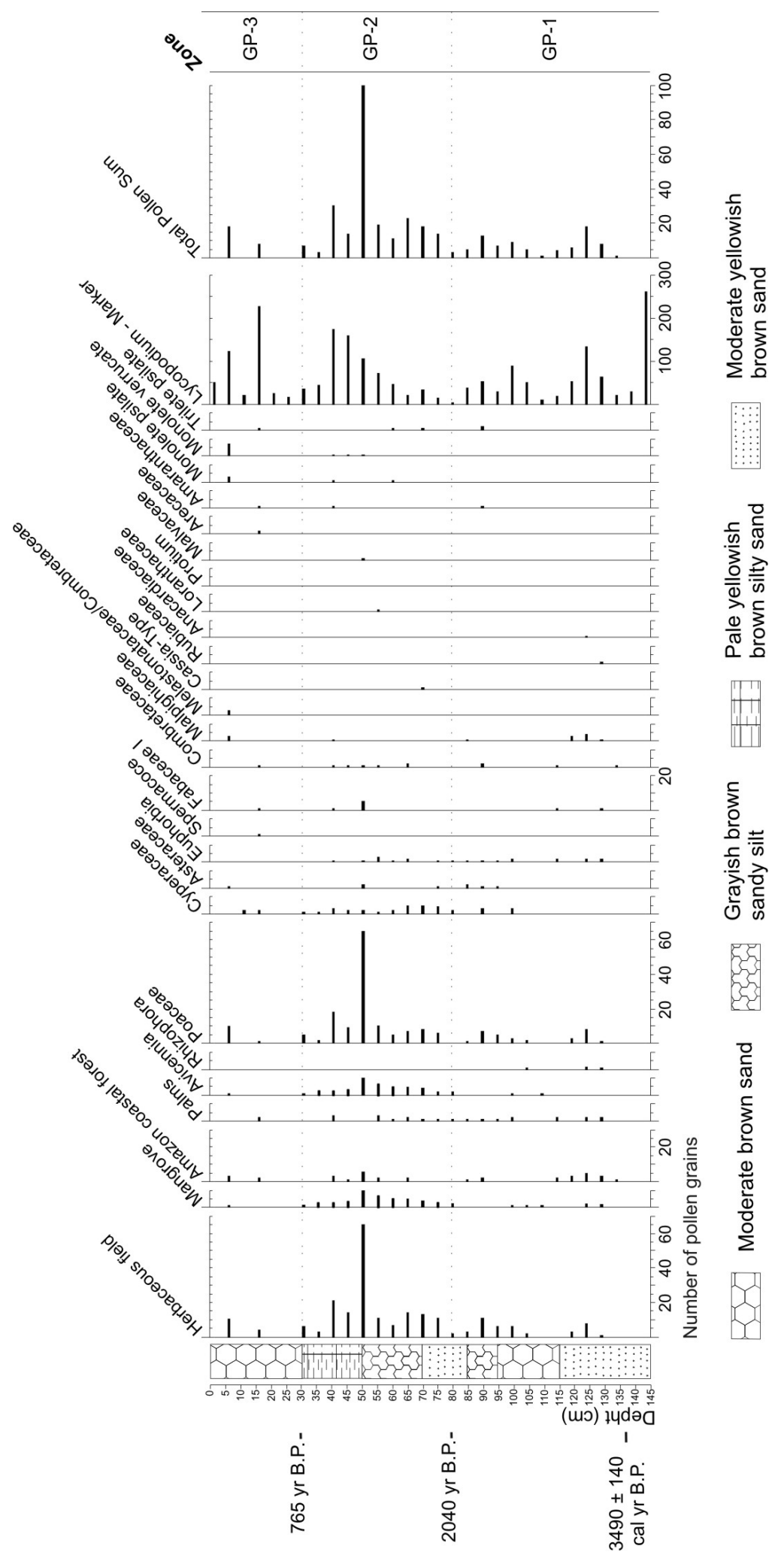

Fig. 4 - Textural description integrated to the pollen profile of Goiabal Praia core. 
The pollen records of sediment cores assume that pollen accumulating in the sediment represents the vegetation above (local vegetation). Thus, the strength of the pollen signal from each kind of vegetation is distanceweighted (e.g. Davis 2000). The dates on the modern pollen accumulation rate from Bragança Peninsulanortheastern Pará coast indicate that, in the mangroves, Rhizophora is a very high pollen producer, while Avicennia and Laguncularia are very low ones. The pollen accumulation rates of Rhizophora and Avicennia on the Rhizophora/Avicennia dominated forest area are about 14.500 and 450 grains $/ \mathrm{cm}^{2} / \mathrm{yr}$, respectively. The pollen traps from the herbaceous plain site, which are located at least 1-2 km away from the next Rhizophora trees and $100 \mathrm{~m}$ away from the next Avicennia, document an average of 410 Rhizophora grains $/ \mathrm{cm}^{2} / \mathrm{yr}$ and an average of 8 Avicennia grains $/ \mathrm{cm}^{2} / \mathrm{yr}$. This indicates that a certain amount of Rhizophora pollen grains can be transported by wind, while wind transportation of Avicennia pollen is very low (Behling et al. 2001). Therefore, regarding the Goiabal sediments, it would be reasonable to propose that the vegetation patterns, which probably extended about $1 \mathrm{~km}$, will be reflected in pollen records of the sediment cores. Those contributions to pollen loading at the sampling site from each vegetation pattern on the landscape will decrease with the increasing distance from the sampling site.

\section{The Wetland Dynamics}

Krauss et al. (2008) described the effects that multiple ecological factors may have on mangrove development, such as salinity, light, nutrients, and flooding impact. In addition, they identified the importance of nontraditional factors - temperature, $\mathrm{CO}_{2}$, and sea-level rise - as important drivers not only to mangrove establishment on a global scale, but also to seedling growth and persistence on a local scale.

Regarding the formation of the sedimentary deposits from mangroves, this can be described by a combination of models that include both lateral accretion and aggradation (e.g. Woodroffe et al. 1989), following the topographic zone of mangrove development (Cohen et al. 2005a). The analysis of sub-environments set within a depositional system by facies variation can indicate lateral sediment accretion. The lateral migration of sub-environments coexisting within a depositional system produces deposits with different characteristics that are superposed upon each other in the stratigraphic column. This mechanism can be driven by changes in the flow energy through, for example, wave action or tidal currents in mangrove forest (e.g. Furukawa and Wolanski 1996, Cohen and Lara 2003, Cohen et al. 2005b). This process can produce displacement of wetland zonation due to modification of topography and flood frequency, imposing gradients in soil salinity. The wetland boundaries are displaced when the soil is inundated by brackish or saline tidal water. Therefore, there is no need to invoke only changes in seawater salinity to explain such vegetation migrations. This can also justify changes in a mangrove dominated by Rhizophora to one predominantly colonized by Avicennia according to changes in the topography, as the first mangrove genus has lower salinity tolerance than the second one.

Physical processes may be used to explain also the transition of terra firme to "várzea" vegetation. However, these mechanisms explain certain wetland migration, such as the "várzea"/mangrove one. Salinity is an essential physicochemical component for the survival of mangrove (e.g. Snedaker 1982, Clark et al. 1998, Alongi et al. 2000), while the "várzea" vegetation has low salinity tolerance (e.g. Wittmann et al. 2004, Junk 2005). Thus, it is probably necessary to invoke changes in tidal water salinity in this case.

\section{Geobotanical Units from Calçoene:}

\section{DeVElopment AND DyNamics}

Pollen records from coastal zones may be useful to identify paleo salinities of estuarine waters, since the plant assemblages, for example on Pará coast (e.g. Behling et al. 2001, Cohen et al. 2005a), follow well-known patterns. Salinity excludes competing and intolerant species (Snedaker 1978), leading to a characteristic species zonation (Baltzer 1970) and predictable types of community structure (Menezes et al. 2003), where the mangroves are more tolerant to soil salinity than the "várzea" forest (Gonçalvez-Alvim et al. 2001). Soil salinity is basically controlled by flooding frequency (Cohen and Lara 2003), position along the estuarine gradient (Lara and Cohen 2006) and volume of river water discharge that depend of regional rainfall (Mörner 
1999, Cohen et al. 2005b). The specific properties of propagules, namely their dispersal characteristics (Rabinowitz 1978), their mass arrival linked to individual storms (Eagler 1952, Pernetta 1993) and their resistance to consumption by predators (Smith et al. 1989), help to explain many features of the mangrove zonation. Flood tolerance (Naidoo 1985, McKee 1993) and the height of ground surface (Baltzer 1969, Chapman 1976) also indirectly control the zonation.

The term 'Mangrove' was used to denote the morpho-dynamic units within which mangrove forests are inserted. It includes the geophysical, geomorphic and biogeochemical components of the area (Thom 1984).

The sedimentary sequences, pollen records and distribution of modern vegetation types obtained from the study site, added to previously published models on mangrove development proposed to the Bragança Peninsula, northern Brazil (Cohen et al. 2005a), allowed to propose a model of wetland development to the Amapá coast according to its flood regime, sea-level and climatic changes during the Late Holocene. Based on these records, four development phases are proposed (Fig. 5):

\section{Phase 1}

The longitudinal profile did not reveal the occurrence of mangrove in the sediment deposited around $2100 \mathrm{yr}$ B.P (Zone GV-1). Sandy sediments covered topographically high areas and tidal flats, while the muddy sediments occupied coastal valleys.

\section{Phase 2}

The limited radiocarbon dates hinder a precise synchronization of the events. However, assuming a regular sedimentation rate within the sediment accumulation rates obtained to the Pará coast (Behling et al. 2001, 2004, Cohen et al. 2005a, b, 2008, Vedel et al. 2006, Lara and Cohen 2008), from 1900 until 1200 yr B.P., the mud progressively filled the depressions and tidal channels. The mangrove probably started its development on the channel edge, and the herbaceous field on the high sectors. At the end of this time period, a brown organic mud was accumulated simultaneously to the herbaceous field at GA and GV sites. Mangrove and the "várzea" forest are still incipient.
At the GP site, between 1100 and 800 yr B.P., an increase in grain-size occurred (silty sand to sand), probably originated from the increase in the water flow energy, which buried the mangrove area, while the GA and GV sectors present transitional environments with herbaceous field/mangrove and herbaceous field/"várzea", respectively (Zone GA-1 and GV-4).

\section{Phase 3}

The interruption of mangrove development in the zones GA-2 and GP-3, between $\sim 760$ and 530 yr B.P., indicates unfavorable conditions to mangrove development in these sectors, which may be due to the decrease in porewater salinity.

During this time interval, the "várzea" vegetation, adapted to fresh water flooding, expanded in GV area. This situation suggests that the study area may have been affected by a decrease in marine water influence.

\section{Phase 4}

Around 500 yr B.P., the environmental conditions favored the mangrove development in GA site, as well as the "várzea" increase in GV site. The distance of the sampling sites to the coastline, which determines the soil salinity with the topography (Lara and Cohen 2006), may explain the simultaneous mangrove occurrence on the GA and the "várzea" colonization on the GV site.

Between 300-80 yr B.P., a retraction of the mangrove area occurred in the GA, while the herbaceous vegetation increased or was kept constant. During this interval, a decrease in the porewater salinity may have occurred again.

The correlation between current patterns of geobotanical unit distribution and palaeovegetation indicates that mangroves and "várzea" forests are migrating over the herbaceous field on the topographically highest part of the studied coast.

\section{CONCLUSIONS}

The integration of pollen data, sediment descriptions and radiocarbon dating (AMS) allowed the assumption of a model of vegetation changes during the last 2100 years in Calçoene coast, Amapá. This study suggests interchanges between marine and freshwater influence. 


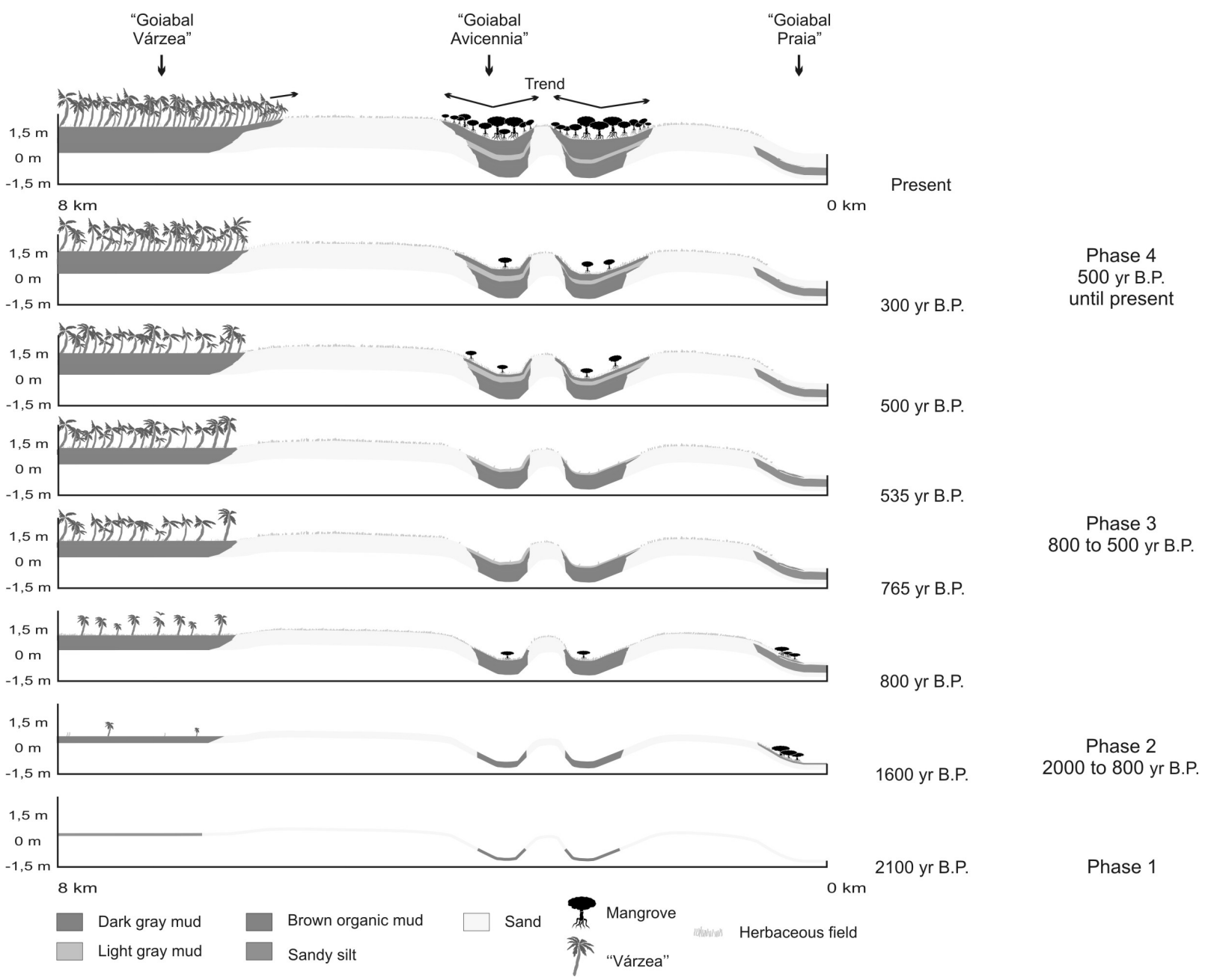

Fig. 5 - Model of wetland development in the Calçoene coastal plain.

The correlation between current patterns of geobotanical unit distribution and palaeovegetation indicates that mangroves and "várzea" forests are migrating over the herbaceous field on the topographically highest part of the study site, which can be related to a relative sea-level rise.

\section{ACKNOWLEDGMENTS}

We thank the members of the Center for Tropical Marine Ecology-Germany and of the Laboratório de Dinâmica Costeira-UFPa in Brazil for their support. This study was supported by the Conselho Nacional de Desenvolvimento Científico e Tecnológico (CNPq) process 562398/20082 and the German Ministry for Education and Research (BMBF) under the code 03F0154A.

\section{RESUMO}

Os tipos de vegetação atual, sequências sedimentares, dados de pólen e datações por radiocarbono obtidas em três testemunhos de sedimento da planície costeira de Calçoene foram utilizados para estabelecer uma história paleoecológica durante o Holoceno superior das zonas úmidas costeiras do Amapá conforme as mudanças no regime de inundação, nível do mar e clima. Baseado nestes três registros, quatro fases de desenvolvimento da vegetação são apresentadas e provavelmente refletem a interação entre o fluxo de energia na acumulação do sedimento e a influência das águas salobras e doces na vegetação. Este trabalho sugere alternâncias entre períodos caracterizados por influências marinha e fluvial. O perfil longitudinal não revelou a ocorrência de manguezais nos sedimentos depositados por volta de 2100 anos A.P. Durante a 
segunda fase, a lama preencheu progressivamente as depressões e canais de maré. Provavelmente, os manguezais iniciaram seu desenvolvimento nas margens dos canais, e os campos herbáceos nos setores elevados. A terceira fase é caracterizada por uma interrupção no desenvolvimento dos manguezais e a expansão da vegetação de várzea devido a uma diminuição na influência das águas marinhas. A última fase é representada pela expansão de manguezais e várzeas. A correlação entre os padrões atuais de distribuição das unidades geobotânicas e a paleovegetação indica que os manguezais e as florestas de várzea estão migrando sobre os campos herbáceos nos setores topograficamente mais elevados do litoral em estudo, o que pode estar relacionado a um aumento do nível relativo do mar.

Palavras-chave: rio Amazonas, mudanças climáticas, manguezal, palinologia, nível do mar.

\section{REFERENCES}

Allison MA, Nittrouer CA, Rine JM, Vital H, Kuehl SA, FARIA JR LEC, Dias GTM ANd FigueREDO JR AG. 1990. Depocenters of Amazon River sediment along the Amapá Coast-Brazil. AGU Fall Meeting. San Francisco. Abstract, 23-31.

Alongi DM, Tirendi F And Clough BF. 2000. Belowground decomposition of organic matter in forests of the mangrove Rhizophora stylosa and Avicennia marina along the arid coast of Western Australia. Aquat Bot 68: 97-122.

ANDERSEN ST. 1970. The relative pollen productivity and representation of North European trees, and correction for tree pollen spectra. Danm Geol Und (II) 96, 99 p.

BALTZER F. 1969. Les formations vegetales associées au delta de la Dumbea (Nouvelle Caledonie). Cah ORSTOM, Ser Geol 1: 59-84.

BALTZER F. 1970. Etude sédimentologique du marais de Mara (Côte ouest de la Nouvelle Calédonie) et de formations quaternaires voisines. Mémoires expédition française sur les récifs coralliens de la Nouvelle Calédonie, Fondation Singer-Polignac 4: 146-169.

Behling H, COHEN MCL AND LARA RJ. 2001. Studies on Holocene mangroves ecosystem of the Bragança Peninsula in north-eastern Pará, Brazil. Palaeogeogr Palaeclimatol Palaeoecol 167: 225-242.

Behling H, Cohen MCL and Lara RJ. 2004. Late Holocene mangrove dynamics of Marajó Island in Amazonia, northern Brazil. Veget Hist Archaeobot 13: 73-80.
BIRD ECF. 1980. Mangroves and coastal morphology. The Victorian Naturalist 97: 48-58.

BoAVEnTURA FMC AND NARITA C. 1974. Geomorfologia da Folha NA/NB.22 - Macapá. In: Projeto RADAM. Projeto de Integração Nacional. Rio de Janeiro: DNPM, Parte II 6: 1-36.

CAHOON DR AND LYNCH JC. 1997. Vertical accretion and shallow subsidence in a mangrove forest of southwest Florida: Mangroves and Saltmarshes 1: 173-186.

Chapman VJ. 1976. Manlal Vegetation of Papua New Guinea, the Philippines and Oceania. In: CHAPMAN VJ (Ed), Mangrove Vegetation. J Cramer Publ, Lichtenstein, $447 \mathrm{p}$.

CHAVEZ PS. 1988. An improved dark-object subtraction technique for atmospheric scattering correction of multispectral data. Remote Sens Env 24: 450-479.

Chavez PS, Berlin GL AND Sowers LB. 1982. Statistical method for selecting Landsat MSS ratios. J Appl Photogr Enging 8: 23-30.

Clark MW, McConchie D, LeWis DW and SAEnger P. 1998. Redox stratification and heavy metal partitioning in Avicennia dominated mangrove sediments: a geochemical model. Chem Geol 149: 147-171.

COHEN MCL. 2003. Past and current mangrove dynamics on the Bragança peninsula, northern Brazil. PhD Thesis. Bremen, University of Bremen. Center for Tropical Marine Ecology, 110 p.

COHEN MCL AND LARA RJ. 2003. Temporal changes of mangrove vegetation boundaries in Amazonia: Application of GIS and remote sensing techniques. Wetl Ecol Manag 11: 223-231.

Cohen MCL, Souza Filho PWM, LARA RJ, Behling H AND ANGUlo RJ. 2005a. A model of Holocene mangrove development and relative sea-level changes on the Bragança Peninsula (Northern Brazil). Wetl Ecol Manag 13: 433-443.

Cohen MCL, Behling H And Lara RJ. 2005b. Amazonian mangrove dynamics during the last millennium: The relative sea-level and the Little Ice Age. Rev Palaeobot Palyno 136: 93-108.

Cohen MCL, Lara RJ, Smith CB, Angélica RS, Dias BS AND PEQUENO T. 2008. Wetland dynamics of Marajó Island, northern Brazil, during the last 1000 years. Catena 76: 70-77.

Colinvaux PA, De Oliveira PE ANd PATiÑo JEM. 1999. Amazon Pollen Manual and Atlas - Manual e Atlas Palinológico da Amazônia. Hardwood Academic, Amsterdam, $332 \mathrm{p}$. 
JOSÉ T.F. GUIMARÃES et al.

Colinvaux PA And De Oliveira PE. 2000. Palaeoecology and climate of the Amazon basin during the last glacial cycle. J Quat Sci 15: 347-356.

Costa Neto SV. 2004. Relatório de vegetação: Subsídio ao diagnóstico sócio ambiental. Relatório Técnico. Macapá: IEPA/GERCO, 32 p.

DAVIS MB. 2000. Palynology after Y2K - understanding the source area of pollen in sediments. Annu Rev Earth P1 Sc 28: $1-18$.

EAGLER FE. 1952. Southeast saline Everglades vegetation, Florida and its management. Plant Ecol 3: 213-265.

FAEGRI K AND IVERSEN J. 1989. Textbook of Pollen Analyses. J Wiley \& Sons Ltd, Chichester, 328 p.

FURUKAWA K AND Wolanski E. 1996. Sedimentation in mangrove forests. Mangroves and Salt Marshes 1: 3-10.

Goddard EN, Trask PD, Ford RK, Rove ON, SingeWALD JT AND OVERBECK RM. 1984. Rock- color chart. Geolog Soc Am, USA.

Gonçalves-Alvim SJ, VAz dos Santos MCF And FERNANDES GW. 2001. Leaf Gall Abundance on Avicennia germinans (Avicenniaceae) along an interstitial salinity gradient. Biotropica 33: 69-77.

GoRnitz V. 1991. Global coastal hazards from future sea level Rise. Palaeogeogr Palaeclimatol Palaeoecol 89: 379-398.

GRIMM EC. 1987. CONISS: a FORTRAN 77 program for stratigraphically constrained cluster analysis by the method of the incremental sum of square. Comput Geosci 13: 13-35.

Herrera LF And Urrego LE. 1996. Atlas de polen de las plantas útiles y cultivadas de la Amazonia colombiana. Tropenbos Colombia, Bogotá, 462 p.

Hutchings P And Saenger P. 1987. Ecology of Mangroves. Queesland University Press, 388 p.

JANSSEN CR. 1973. Local and regional pollen deposition. In: BIRKS JHB AND WEST RG (Eds), Quaternary plant Ecology. Blackwell Scientific, Oxford, 326 p.

JUNK WJ. 1997. The Central Amazon Floodplain: Ecology of a Pulsing System. Springer, New York, 525 p.

JUNK WJ. 2005. Flood pulsing and the linages between terrestrial, aquatic, and wetland systems. Verh Int Ver Theor Angew Limnol 29: 11-38.

Krauss KW, Lovelock CE, McKeE KL, López-HoffMAN L, EWE SML AND SousA WP. 2008. Environmental drivers in mangrove establishment and early development: A review. Aquat Bot 89: 105-127.
LACERDA LD, ITteKKot V AND PATChineElam SR. 1995. Biogeochemistry of mangrove soil organic matter: a comparison between Rhizophora and Avicennia soils in South-eastern Brazil. Estuar Coast Shelf Sci 40: 713-720.

LARA RJ AND COHEN MCL. 2006. Sediment porewater salinity and mangrove vegetation height in Bragança, North Brazil: an ecohydrology-based empirical model. Wetl Ecol Manag 14: 349-358.

LARA RJ AND COHEN MCL. 2008. Palaeolimnological studies and ancient maps confirm secular climate fluctuations in Amazonia. Climatic Change 94: 399-408.

Leite PF, Veloso HP AND Góes Filho L. 1974. Vegetação da Folha NA/NB.22-Macapá. In: Projeto RADAM, Projeto de Integração Nacional. Rio de Janeiro: DNPM, Parte I 6: 9-40.

Maslin MA, Burns SJ, Durham E, Greig S, Grootes P, Nadeau MJ, Platzman E, Schleicker M And SCHNEIDER R. 2000. High resolution marine palaeoclimate records of the Amazon River discharge over the last 12,000 years. J Quat Sci 15: 419-434.

MCKEE KL. 1993. Soil physicochemical patterns and mangrove species distribution: Reciprocal effects? J Ecol 81(3): 477-487.

Menezes M, Berger U And Worbes M. 2003. Annual growth rings and long-term growth patterns of mangrove trees from the Bragança peninsula, North Brazil. Wetl Ecol Manag 11(4): 233-242.

Morais PD AND Morais JD. 2000. O Amapá em Perspectiva: uma abordagem histórico-geográfica. Editora Valcan, Macapá, 200 p.

MÖRNER NA. 1999. Sea-level and climate: rapid regressions at local warm phases. Quatern Int 60: 75-82.

NAIDOO G. 1985. Effects of waterlogging and salinity on plant water relations and on the accumulation of solutes in three mangrove species. Aquat Bot 22: 133-143.

PERnETTA JC. 1993. Mangrove forests, climate change and sea-level rise: hydrological influences on community structure and survival, with examples from the Indo-West Pacifi. A Marine Conservation and Development Report. IUCN, Gland (Switzerland), 46 p.

RABINOWITZ D. 1978. Early growth of mangrove seedlings in Panama, and an Hypothesis concerning the relationship of dispersal and zonation. J Biogeogr 5: 113-133.

Roubik DW AND Moreno JE. 1991. Pollen and Spores of Barro Colorado Island. Missouri Botanical Garden, $268 \mathrm{p}$.

SANGSTER AG AND DALE HM. 1961. A preliminary study of differential pollen grain preservation. Can J Bot 39: $35-43$. 
Sangster AG And Dale HM. 1964. Pollen grain preservation of underrepresented species in fossil spectra. Can J Bot 42: 437-449.

SchaefFer-Novelli Y AND Cintron-Molero G. 1988. Expedição nacional aos manguezais do Amapá, Ilha de Maracá. Relatório técnico. Brasília: CNPq, 99 p.

SCHOLL DW. 1964. Recent Sedimentary Record in Mangrove Swamps and Rise in Sea Level Over the Southwestern Coast of Florida: Part 1. Mar Geol 1: 344-366.

Smith TJ, Chan HT, McIvor CC And Robblee MB. 1989. Comparisons of seed predation in tropical tidal forests from three continents. Ecology 70: 146-151.

SNEDAKER SC. 1978. Mangroves: their value and perpetuation. Nature Resour 14: 6-13.

SNEDAKER SC. 1982. Mangrove species zonation: Why? In: SEN DN AND RAJPUROHIT KS (Eds), Tasks for vegetation science. Dr W Junk Publishers, The Hague, p. 111125.

SPENCELEY AP. 1982. Sedimentation patterns in mangal on Magnetic Island near Townsville, North Oueensland. AustraKa. Singapore J Trap Geog 24: 100-107.

SugITA S. 1994. Pollen representation of vegetation in Quaternary sediments: theory and method in patchy vegetation. J Ecol 82: 881-897.

Stuiver M, Reimer PJ, BArd E, Beck JW, Burr GS, Hughen KA, Kromer B, McCormac G, van der Plicht J AND SPURK M. 1998. INTCAL98 Radiocarbon Age Calibration, 24000-0 cal BP. Radiocarbon 40: 1041-1083.

THOM BG. 1984. Coastal landforms and geomorphic processes. In: SNedAKer SC AND SNEdAKer JG (Eds), The Mangrove Ecosystem: Research Methods. Monographs on Oceanographic Methodology, vol. 8. UNESCO, United Kingdom, p. 3-17.
VAN DE PLASSCHE O. 1986. Sea level research: A manual for the collecion and evaluation of data. Geobooks: Norwich, $615 \mathrm{p}$.

Vedel V, Behling H, COHEN MCL ANd LARA RJ. 2006. Holocene mangrove dynamics and sea-level changes in Taperebal, northeastern Pará State, northern Brazil. Veget Hist Archaeobot 15: 115-123.

Vital H And Stattegger K. 2000. Lowermost Amazon River: evidence of late Quaternary sea-level fluctuations in a complex hydrodynamic system. Quatern Int 72: 5360 .

Wittmann F, Junk WJ And Piedade MTF. 2004. The várzea forests in Amazonia: flooding and the highly dynamic geomorphology interact with natural forest succession. For Ecol Manage 196: 199-212.

Wolanski E, Mazda Y, King B And Gay S. 1990. Dynamics, flushing and trapping in Hinchinbrook Channel, a giant mangrove swamp. Estuar Coast Shelf Sci 31: 555-579.

Woodroffe CD. 1981. Mangrove Swamp Stratigraphy and Holocene Transgression, Grand Cayman Island, West Indies. Mar Geol 41: 271-294.

Woodroffe CD, Chappell J, Thom BG AND WALlenSKY E. 1989. Depositional model of a macrotidal estuary and flood plain, South Alligator River, northern Australia. Sedimentology 36: 737-756.

Youssef T AND SAENGER P. 1999. Mangrove zonation in Mobbs Bay-Australia. Estuar Coast Shelf Sci 49: 43-50. 